\title{
Translation at the Service of Greater Britain
}

\author{
Simon McKinnon* \\ School of Modern Languages \& Cultures \\ Durham University \\ Elvet Riverside, New Elvet, Durham DH1 3JT, UK
}

Received 21.11.2014, received in revised form 14.12.2014, accepted 06.01.2015

The late-medieval French text, the Débat des Hérauts d'armes does not provide an explicit argument in support of early or, for that matter, later British imperial aspirations. It does not even present the English in a particularly good light. Henry Pyne's translation of this text in 1870 as a vehicle for the promotion of what his contemporary Sir Charles Dilke termed Greater Britain would therefore seem to be problematic. Nevertheless, this paper will argue that by surrounding his translation with extensive paratextual material, Pyne presents his text as an important document explaining Britain's historical relationship with Europe and the wider world. More specifically, Genette's understanding of paratexts as a means of limiting the reader's interpretive options will be used to investigate the ways by which Pyne, through the title, prefaces, footnotes, endnotes, investigation into authorship and conclusion, ensures a reading of the text consistent with an interpretation of history supporting a particular set of late nineteenth-century British ideas about race, national character and Anglo-Saxon colonial 'destiny'. The paper will therefore offer further insight into the ways in which translation has been used not to challenge hegemonic cultural discourse but rather to promote and reinforce dominant ideological positions.

Keywords: Translation history, paratexts, Greater Britain, Débat des hérauts d'armes.

Research area: philology.

\section{Paratexts and translation}

In his seminal study of paratexts, Gérard Genette explains that they are fundamental to the way readers recognise and navigate books. Genette writes that paratextual material, that is titles and authorial identification, prefaces, introductions, footnotes and endnotes, illustrations, even bindings, dust jackets and advertising, "is what enables a text to become a book and to be offered as such to its readers" (1997: 1). Moreover, such paratextual material has an important function in relation to the way readers interpret and understand texts since it organises and directs their reading and, at the same time, inevitably closes down their interpretive options. As Genette puts it, paratexts function to ensure that the text is read in the way the author intended, to ensure a more "pertinent reading of it" (ibid.: 2). Paratextual material exercises a significant influence over readers, subtly manipulating their experience of the text (ibid.: 407-9). It establishes expectations, provides contextualisation and offers authoritative explanations.

(C) Siberian Federal University. All rights reserved

* Corresponding author E-mail address: s.g.mckinnon@durham.ac.uk 
In translation, where the translator mediates the source text for the reader, paratexts play a potentially even more prominent role in establishing what the translator perceives to be a "pertinent" reading of the text. Translator's notes, introductions and glossaries are frequently used to bridge the gap between source and target cultures by supplying the cultural information and contextualisation that the target-text reader lacks. Two recent collections by Gill-Bardají, Orero and Rovira-Esteva (2012) and Pellatt (2013) have illustrated the ways studies of paratexts can be effectively used to interrogate translations from a range of different perspectives. A number of other studies have focused on the powerful influence exerted by paratextual material in establishing the ideological context within which any translation is read (Kovala 1996; Tahir-Gürçaglar 2002; Harvey 2003). In particular, Kovala's discussion of "ideological closure" helps us understand how paratexts are themselves "mediators between the text and reader", ideologically shaping reception of the translated text as well as perceptions of the source culture (1996: 120). Consciously or unconsciously, translators reflect their own or their culture's "modes of thinking, forms of evaluating and codes of behaviour" whenever they translate (Calzada Pérez 2003: 5). An analysis of paratexts can therefore be useful not only as a means of better understanding the ways one culture perceives another but also as a means of understanding the ways a culture perceives and presents itself when faced by ideas of cultural difference and otherness.

\section{Henry Pyne and 'Greater Britain'}

Henry Pyne's 1870 English translation of the late-medieval French Débat des hérauts d'armes [Debate between the Heralds] provides a good example of the dynamic relationship between text, paratext and cultural/ideological self-perceptions. Although the source text is much too early to include any discussion of either English or French colonialism, Pyne surrounds his translation of it with extensive paratextual material in order to present it unambiguously as early evidence of an English/British colonialdestiny. Pyne's translation can thus be situated within a broader context of intense public debate in Britain towards the end of the nineteenth century about the future of the empire and, in particular, the "Anglo-Saxon" or settler colonies in Canada, Australia, New Zealand and South Africa. Pyne was translating at a key moment in the development of this debate: just two years after the founding of the Colonial Society (later the Royal Colonial Institute) and the publication of Sir Charles Dilke's Greater Britain. Dilke's ideas were hugely influential and his broad conceptualisation of the British empire as straddling the political, cultural and racial domains was quickly taken up by numerous later writers and thinkers (Bell 2007: 1-24). The relative openness of the idea gave it wide-ranging appeal:

"Greater Britain meant different things to different people [...]. The term was employed in three main ways. Firstly it could denote the totality of the British empire, the vast ensemble of disparate territories coloring the map red. Secondly, it could refer to the settlement colonies, which by the 1870 s were growing very rapidly in population, economic power and strategic importance. And thirdly, it could mean the "English-speaking" or Anglo-Saxon countries of the world, encompassing not only the settlement empire but also the United States" (ibid.: 7).

It is with this third understanding of Greater Britain that Pyne explicitly associates his text. Pyne was not a well-known historian, a professional political theorist nor a noted 
translator; in fact, he was a barrister, employed as 'Assistant Tithe Commissioner' and best known for his Tables Showing the Value of Tithe RentCharges under Every Variation in The Price of Corn (1838). Nevertheless, in 1850, at the height of the controversy surrounding the re-establishment of the Roman Catholic hierarchy in England, he had published a re-edition of a Reformation polemic succinctly entitled, A Treatise Proving by The Common Law that The Pope Never Had Right to Any Supremacy in England. He clearly knew how to exploit early material in the service of current debate. This paper will argue that by 1870, Pyne was one of what Duncan Bell, in the context of ideas about empire, describes as "the elite class of academics, businessmen, lawyers, politicians and journalists - often combining several of these roles simultaneously - who shaped public debate in London, the imperial metropolis" (2007: 6). It will argue that Pyne uses his translation of the French Débat to set the latenineteenth century British imperial and colonial project within a teleological account of English and British history beginning with the expulsion of the English from France in 1453 and the shift of their political ambitions away from Europe. It will also argue that it is through paratextual material that Pyne directs and manipulates his reader in order to ensure what he considered to be a 'correct' reading of the translation: that is one which sees the text as evidence supporting a particular ideology of race, national character and Anglo-Saxon colonial 'destiny'. Ultimately, then, Pyne uses his translation not as a way of challenging the reader with an image of political failure and cultural otherness but rather as a means of reinforcing dominant contemporary ideological discourse.

\section{The Débat des hérauts d'armes}

Pyne was a successful collector of early printed books, eventually building up a collection that warranted an individual sale by Sotheby's after his death in 1885 (Sotheby 1886). It was almost certainly in the context of this interest in rare books that he came across an early printed edition of the then relatively unknown Débat des hérauts d'armes, though he does not seem to have ever owned a copy himself. Pyne tells us in his introduction that he used the printed edition held in the British Library as his source text; he was not aware of the existence of any other versions (xi). In fact, the Débat circulated in several manuscript versions in the fifteenth century before being printed in at least three different editions at the beginning of the sixteenth century. A full modern French critical edition would not be produced until 1877 when, inspired by Pyne's translation, the text was published by the prestigious Société des anciens textes français (Pannier and Meyer 1877).

In terms of its form and content, the Débat is a relatively conventional text for the latemedieval period: it is a fictional prose 'debate' of about 14, 000 words set within an allegorical framework in which Prudence, meeting the heralds of France and England in a garden, asks them to demonstrate which of their kingdoms is the most worthy of a place next to the throne of Honour. Arguments are made then refuted, one after the other, with each herald presenting the merits of his own kingdom while criticising the shortcomings of the other. This all takes place at some point shortly after the battle of Castillon ending the Hundred Years War and centuries of English involvement in France. In spite of the fact that Prudence reserves her judgement at the end, the work was produced for a French readership and functions fundamentally to praise the preeminence of the kingdom of France and the French: praise of France and criticism of England far outweighs praise of England, and there is virtually no criticism of France. Nevertheless, this text performs a useful double function for 
Pyne. First, it implicitly marks the end of English feudal and dynastic ambitions on the continent and therefore marks a turning point in English history. Secondly and more importantly, by systematically comparing and contrasting each kingdom, it presents England and France as distinct, each with their own history, geography, customs and economy. Crucially, this provided Pyne with what he saw as evidence of early national distinctiveness and, more particularly, evidence of the unique national character of the English.

\section{The Debate between the Heralds of France and England}

Pyne's approach to translation of the source text itself is surprisingly conservative given that much of it presents the English in a poor light. He does not, for example, adopt the strategy of his sixteenth-century counterpart, John Coke, who, in his 1549 English translation of it, had transformed and manipulated the text, significantly changing whole sections, substituting the English for the French and the French for the English, and adding pages of new material in order to reverse the fundamental arguments of the text (Pannier and Meyer 1877: 53-125). Pyne retains the structure and organisation of his source and consistently attempts to provide an honest and accurate rendering of its sense. Where possible, he reproduces or at least echoes the basic syntactic structures of the original, avoiding substantial reworking of sentences and even clauses unless necessary for clarity and coherence. To some extent, the age of the source text makes this task easier since unusual syntax can simply be passed off as reflecting an archaic form of English. Even after taking this into account, the translation still reads fluently and easily throughout. In terms of lexis, Pyne's approach is similarly conservative. He does not attempt to employ the lexicon or non-standard orthography of the early sixteenth-century but instead uses a mixture of archaic words, formal terms from his own period and cognate forms inspired by the source text. Thus, the translation does not attempt to provide an authentic imitation of Middle English but rather a convincing, readable representation of 'old material' in an English 'of the past'. A comparison of the opening lines in both source and target texts illustrates the approach taken by Pyne throughout the work:

"Prudence ung jour se esbatoit en ung preau, et se trouva acompaignée de deux heraulx : l'un estoit herault de France et l'autre d'Angleterre. Si se appensa Prudence de leur faire une question pour savoir s'ilz estoient savans et expers en leur office, et leur print a raisonner en la maniere qui s'ensuit :

Beaulx seigneurs, dist Prudence, vous avez ung bel office, et que tous nobles doivent amer et priser, car a voz rappors et relacions les roys, les dames, les princes et autres grans seigneurs jugent des honneurs mondains [...] (text as in Pannier and Meyer 1877 with variants according to the edition used by Pyne: 1).

"As Prudence was one day diverting herself in a garden, she fell into the company of two heralds, one of whom was the herald of France, and the other of England. So Prudence thought she would ask them a question, in order to find out whether they were learned and skilful in their office; and she began to discourse with them in the following manner :-

"Fair sirs," said Prudence, "you hold a goodly office, and one which all noblemen ought to love and esteem, since by means of your reports and information, kings, princes, ladies and 
other great lords form their judgement of worldly honours [...]" (3).

There is only one significant omission. In the edition used by Pyne as his source, the text ends with a very early printing of François Villon's Ballade contre les ennemis de France [Ballad against the enemies of France] (Pannier and Meyer 1877: 183-8). This poem is entirely missing from Pyne's translation though its presence in the source text is mentioned briefly in an endnote (121). Unlike the rest of the Débat, Villon's Ballade makes no pretence of balance or diplomacy and is a vituperative, patriotic attack against those "Qui mal vouldroit au royaume de France" [who would wish ill of the kingdom of France] (Pannier and Meyer 1877: 184-5). In the printed edition, this paratextual ballad clearly contributes to the tone and function of the work as a whole: a long, reasoned depiction of the greatness of France ends with a short, rousing patriotic invective, all reinforcing the reader's self-identification with the kingdom of France. Pyne offers no rationale for omitting the ballad. This omission is, nevertheless, understandable, given Pyne's focus on presenting the Débat as an important document illustrating English history. By omitting the source text's own powerful paratextual material, Pyne avoids confusing his reader with a discordant or problematic reading of the translation and instead focuses attention on a reading that more clearly serves his own purposes.

\section{Framing paratexts}

Indeed, Pyne leaves nothing to chance; he guides and cajoles his reader at every opportunity. For 88 pages of translated text (including footnotes), there are 133 pages of paratext. Nearly all of the paratextual material is authored directly by Pyne himself though the role of his publisher, Longmans, Green and Co., must be taken into account in relation to certain features such as selection of the work's title or the inclusion of advertising material at the end. On the title page, we are told in detail what to expect: "ENGLAND and France in the Fifteenth Century. The Contemporary French Tract entitled 'The Debate between the Heralds of France and England,' presumed to have been written by Charles, Duke of Orleans: TRANSLATED FOR THE FIRST TIME INTO ENGLISH; WITH AN INTRODUCTION, NOTES, AN INQUIRY into the authorship, etc. By Henry Pyne." The title has several functions: it foregrounds the historical pretensions of the work, indicating that the translation has something to tell us about England and France in this period more broadly; it identifies a "presumed" author in a well-known, respected historical and literary figure; it suggests a work of authority, containing the full critical apparatus of scholarship; finally, it identifies Pyne as the translator. From the outset, the reader is primed with a clear idea of the kind text to expect. Even the publisher's imprint, appearing directly beneath the title (though standard practice in the nineteenth century as now), reminds the reader that the work has been produced by a well-known and respected publisher. In fact, Longmans had a long and successful record of publishing historical works as well as biographies and works on philosophy, politics, natural history, medicine and science among other things (Briggs 2008: 229-92). Details of many of these works, including Macaulay's immensely successful History of England from the Accession of James II, J.A. Froude's The History of England from the Fall of Wolsey, Thomas Erskine May's The Constitutional History of England since the Accession of George III and Herman Merivale's Historical Studies, can be found in the advertisements at the end of the book. Although Pyne almost certainly had no input into the decision to include this advertising material, it is interesting all the same because it influences a reading of his text by associating it with a long list of important writers of history. 
Implicitly, readers who appreciate Pyne would also appreciate Macaulay, Froude, May, et al. and vice versa. Moreover, many of the historians listed in these advertisements were themselves closely involved in the cultural re-imagining of a British imperial and colonial future (Bell 2007; Koditschek 2011).

\section{Preface, Introduction and Notes}

Two shorter paratexts come directly before the translation: a 3 page "preface" followed by a 10 page "introduction". The preface simply expands upon the title page, setting out in greater detail what the reader can expect and explaining the structure of the work as a whole. The introduction serves as a summary or 'abstract' of the main arguments and ideas, again, preparing the reader by hinting at what is to come. It identifies the source material used and briefly acknowledges the existence of Coke's 1549 version (described as a "trivial and unsatisfactory" "reply" to the original rather than a translation (xiii-xiv)) but it also introduces the idea of national distinctiveness (xv-xvi) and argues for the importance of the work as a historical document produced at the "commencement of modern history" (xvi).

Pyne's footnotes and endnotes are of much greater interest to the present study as it is in these that he explicitly interprets and comments on the details of the text and, in so doing, closes down the reader's interpretive options. There are 69 footnotes in total, each printed under the main text but in a smaller font. Of these, 56 are mainly explanatory, that is, they provide information about potentially obscure historical figures or events or other cultural references in the text without suggesting the need for a significant correction to the source material. The remaining 13, however, explicitly correct what Pyne considers to be erroneous facts or opinions. For example, in response to the argument that, unlike French kings who were "free" and did not hold their kingdom "under any superior", English sovereignty was held "by compact of the See of Rome" and English kings were "tributary to it in the yearly sum of a thousand silver marks", Pyne provides a long explanation of the history of 'Peter pence', an annual financial contribution given by the English Church to Rome, and concludes that "there never was any pretence for affirming that the Peter pence was a rent of base tenure, or implied a submission derogatory to the sovereignty of England" (31). Elsewhere, the text blames the English for exploiting French internal division in order to prolong the Hundred Years War

"When you knew of this war and division, you came forward with offers to the Duke of Orleans on the one hand, and to the Duke of Burgundy on the other, and you flamed and exasperated the war by every means which you could conceive."

Here, it was much harder for Pyne to draw on historical sources to convincingly provide a concise refutation of this argument. Instead, he resorts to the authority of opinion as 'fact':

"The responsibility of renewing the war with France rests with the French princes rather than with Henry V., since he only availed himself of their offers, and did not himself come forward in the first instance. Every contemporary historian admits this fact" (my italics) (43).

In a similar vein, Pyne firmly contradicts the text's presentation of the French king, John the Good's behaviour at the Battle of Poitiers (1356) as courageous, with the king preferring "rather to die or to be taken prisoner" than to retreat. Pyne simply comments that:

"King John, though an honourable and brave cavalier, was deficient in the higher order of courage, or he would 
not have signed the Treaty of Bretigny; and Philip de Comines, who was quite ready to make all fair allowances for kings, has held up to reprobation his conduct in thus sacrificing the welfare of his people to procure his own release from captivity" (35).

Such comments and corrections attenuate the francocentric focus of the source and do enough to call some of its other critical remarks about the English into question without undermining its reliability (and Pyne's presentation of it as an important historical document) altogether. At the same time, Pyne is able to present himself as an erudite and knowledgeable scholar able to give an authoritative account of history. Moreover, his aim is not to present late-medieval England as an example of the ideal state, ideally governed. As we shall see in his 'conclusion', his account fits neatly within the dominant nineteenth-century historical discourse which saw England and the Britain as evolving progressively from medieval obscurantism and backwardness towards contemporary greatness precisely by casting off what was perceived as oppressive feudalism, the corruption of the Roman Church and the pretensions of monarchy to absolute government (Bell 2007; Koditschek 2011).

This combination of erudite scholarship and ideological comment is most effective in the 30 pages of endnotes that follow the translation. Here, again, 42 detailed notes are printed in a smaller font than the rest of the work. Many of these notes simply provide fuller and more detailed historical contextualisation of the material found in the text, explaining, for example, why Judas Maccabeus is included in the list of nine worthies (92), why French kings called themselves the "Greatest of Christian kings" (93) or how precisely Goshawks differ from Tercelets (98). In a few notes, Pyne does call the source material into question: in one, for example, he questions the text's reasoning (114); in another, he argues that what the text claims to be a strength is, in fact, a weakness (113). However, Pyne's main strategy in this section is to undercut the pro-French bias of the source by providing ample evidence of English greatness. Thus, among other things, we are told of the abundance of wild fowl in England (93), of English claims to have also had the first Christian king (100), of the their contribution to the Crusades (101), of the longstanding alliance between England and Portugal (108) and of the country's natural beauty: "the native of these isles, when he returns home to his own country, must be blind if he fails to perceive in it another kind of beauty which all nations have admitted to exist in full perfection there" (118). Pyne also expands the exegesis in these endnotes in order to include elements of a historical narrative of English 'progress' that he will develop much further in his conclusion. This narrative exploits key themes in contemporary historiography: that the English are 'naturally' protestant (102); that, post Reformation, they have been surrounded by hostile catholic powers (109); that the Stuarts were to blame for the decline in the country's prestige $(94,99)$; that the Commonwealth was an interlude during which "England stood upon its feet" (94), that after the Revolution of 1688, England began to recover its power and status (95). Of course, none of this is found in the source text (not least because most of the events postdate it), but, by inserting this narrative into the notes, Pyne exerts an important influence on any reading of the translation because the narrative now sits alongside the source material and becomes part of the reader's experience of the text as a whole.

\section{Authorship}

The longest of Pyne's paratexts is a 57 page "Inquiry" into the authorship of the text (125-181), directly following the endnotes. His objectives here are clearly set out in the opening lines: 
"Although the intrinsic merit of the 'Debate between the Heralds of France and England' may be sufficient to warrant the publication of that work in English, yet since its value as an historical authority will be more precisely determined if the author of it can be discovered, the following observations have been brought together for the purpose of solving the question" (125).

Pyne thus sees his document and, by extension, the arguments and ideas he associates with it, as being historically more important if it can be identified with a specific author but he is not satisfied with just any author; the candidate he selects is the well-known and respected historical and literary figure, Charles d'Orléans (13941465). Such an author would lend authority to the text because d'Orléans had first-hand knowledge and experience of both France and England, was of sufficiently high social status to be able to present an accurate picture of the political and historical events described in the text, and his literary skills and accomplishments were already acknowledged. Moreover, attribution of a new work to d'Orléans would clearly attract attention to Pyne's translation from scholars within Britain and also in France. Unfortunately, Pyne's arguments, though detailed, were rather weak: many of the themes and images found both in the Débat and in d'Orléans's patriotic poetry were, in fact, well-known stereotypes also found in numerous other works of the period; much of the historical evidence provided (for example, similarities between the description of England in the Débat and the physical geography of the places where d'Orléans was held captive during the Hundred Years War) is circumstantial. Indeed, Pyne's attribution of the Débat to d'Orléans was rejected as early as 1877 by the editors of the French text (Pannier and Meyer 1877: vii-xii).
Nevertheless, in terms of a reading of Pyne's translation, this paratextual material effectively answers potential questions about the authorship and authority of the text and further circumscribes the reader's interpretive options.

"God had not utterly forsaken our country, for there was important work still left for her to perform"

It is in his "Conclusion" that Pyne most fully develops his broader historical narrative and his ideological positions. At 35 pages (185-219), this conclusion is a substantial piece of writing. First, Pyne provides a rationale for what will follow: "Now that four centuries have elapsed, we are able to cast a glance abroad, and to recognise with more clearness the influences which were then in operation" (185). Next, he depicts, at some length, the fifteenth century as a turning point in history during which the seeds of the modern world were sown: the old system of social organisation based around catholicism and feudalism began to collapse; infighting and power struggles took hold amongst the ruling élites; new knowledge and ideas spread west from Constantinople; and America was discovered (185-94). Then, in describing the end of the Hundred Years War, Pyne introduces an argument that is fundamental to his understanding of the importance of his text as a historical document. That is, that the expulsion of the English from France was not a failure but rather a moment that allowed both the English and French to pursue their own, distinct 'national' destinies separately (195-6). For England, at least, and for quite some time after the Hundred Years War, this destiny was not a particularly happy one. Pyne conveniently skips past the Tudor period, which does not comfortably fit within the objectives of his narrative, to remind us that:

"It was the fortune of England in the seventeenth century to be governed by a dynasty of kings whose policy tended 
to enfeeble and debase their people, and who would have ruined the character of any people which had offered to them a less determined resistance" (202).

He then expands upon this idea to explicitly link an "enthusiastic attachment to liberty, and the power of endurance unto the end in its defence" with the "natural' character of the English; the "freedom enjoyed by the English" was something "they had brought with them out of the forests of Germany" and which "they had never ceased to insist upon as their inalienable heritage" (205). Thus, for Pyne, it is the combination of national character and historical events that led the English to look further afield and to use their energy in the building of a colonial empire:

"At last the English dominion in France had come to an end [...] and we English at the present day cannot wish that the event should have been reversed [...]. And now the business of England henceforth was to improve her own institutions; to become the champion of the approaching Reformation; to uphold the cause of civil and religious liberty; to fight for the independence of Europe; to afford an example of free, secure and progressive government; and no longer to squander her race over the old barren fields of feudal ambition, but to plant it in the virgin soil of more promising lands, where it might increase and multiply [...]. At home her laws, and abroad her fleets and armies, have had for their object not to conquer and enslave, but to liberate. That is the aim of her empire" (209-10).

Pyne goes on to argue that this empire is not merely or even essentially political. As the product of "the scattered bands of Englishmen who went forth to plant the Wilderness", it includes the United States as well as the then existing British settler colonies (211-2). Adopting the contemporary discourse of race and Anglo-Saxonism (Bell 2007: 113-19), he argues that the English and their descendants "instinctively avoiding all commixture with surrounding inferior races" have set out to "fill up the void places of the earth" (209-10). This racist discourse is not incidental; it is developed and expanded in the following five pages. Pyne explains that the Anglo-Saxon 'race' is 'adapted for the assimilation of the other superior races which might come into contact with it" but that it is "incapable of being absorbed" (213). Thus, the Spanish, Portuguese and French have all "intermarried with the native populations" and become "Mexicans, Peruvians, Chilians, Venezuelans", "Brazilians" and "Canadians" whereas the English of America have remained "Anglo-Americans" (212). Further reflecting Dilke's image of a Greater Britain including the United States, Pyne goes on:

"The English race has preserved beyond the Atlantic the lustre of the European family. Like the broad river separating that part of the Northern continent which remains attached to the mother country from the other which has established itself independently, the race flows on unaffected in its depths by the streams which run into it. [...] the Anglo-Americans are of our blood, bone and flesh. They are proud of their Anglo-Saxon descent, and not without reason" (215-6).

Pyne's conclusion makes his translation current. The reader no longer understands his material as an objective historical source but rather as evidence of an important step on the way to colonial greatness. This paratext firmly inserts the translation into a specific historical and ideological discourse. 


\section{Conclusion}

Paratextual material has the potential to shape and even control the reading of any text. The reading of translations is particularly open to paratextual influence because the translator mediates the text for the reader and stands as an authority not only on the source text but also on the culture in which it was produced. As the meeting point of different cultures and different ways of thinking about the world, translation is "always the site of ideological encounters" (Calzada Pérez 2003: 1). Many translations, therefore, play a crucial role in questioning the dominant cultural discourse: traditions, histories, ideologies. The target culture understands itself in new ways after encountering difference and otherness in translation. However, translation may also be used to confirm and reinforce a particular version of the target culture's image of the other or of its own self-image. Here, readers can rarely be left to make up their own mind; texts themselves are potentially too open to uncertainty and offer too many divergent readings; the translator may need to guide the reader through the text in order to ensure an ideologically 'correct' reading of it.

This is the strategy adopted by Pyne in his translation of the Débat des hérauts d'armes. Keen both to present himself as an erudite authority on his subject and to control his reader's interpretation of a potentially problematic text, Pyne surrounds his translation with extensive, interpretive paratexts. Some of this material (the title, preface and introduction) establishes the reader's expectations and conforms to a particular kind of scholarly writing. Footnotes and endnotes clearly establish the translator's erudition but they also attenuate the impact of the source material's fundamentally pro-French position, making it 'readable' for a nineteenthcentury British public. A number of endnotes also begin to situate the text within the specific historiographical tradition associated with the historical works listed in the advertising material at the end. The investigation into authorship is an attempt to lend authority to the source material and possibly to attract a broader readership. Finally, in his conclusion, Pyne firmly sets his material within the dominant historical discourse to which he had alluded in his endnotes and, at the same time, within a discourse of "Anglo-Saxon" empire, colonialism and Greater Britain. These paratexts become part of the reader's experience of the text and, in this way, are inseparable from it. Pyne's reader encounters praise of England, a narrative of the history of post sixteenth-century England/ Britain and a discussion of the Anglo-Saxon colonial project as well the core material found in the source. A reading of Pyne, then, is very different from a reading of the sixteenth-century source text or even of Pannier and Meyer's 1877 French edition of it. Pyne's translation is not ideologically neutral. He very clearly sets his translation to the service of a particular ideology and he does this through the use of extensive paratextual material.

\section{References}

Primary sources

Target text:

1. Pyne, Henry (1870) England and France in the Fifteenth Century: The Contemporary French Tract Entitled 'The Debate between the Heralds of France and England,' presumed to have been written by Charles, Duke of Orleans. Translated for the First Time into English; with an Introduction, Notes, An Inquiry into Authrorship, etc. by Henry Pyne. London: Longmans, Green and Co. 
Source text:

2. Le debat des heraulx d'armes de France et d'Engleterre (n. d.). Rouen: Richard Auzoult for Thomas Laisne. [Pyne's source: British Library C $32 \mathrm{~g} 4$ ]

3. Pannier, Léopold, and Paul Meyer (eds) (1877). Le Débat des Hérauts d'Armes de France et d'Angleterre: suivi de The Debate Between the Heralds of England and France by John Coke. Paris: Société des anciens textes français.

Other:

4. Pyne, Henry (1838). Tables Showing the Value of Tithe Rent-Charges under Every Variation in The Price of Corn. London: Charles Knight and Co.

5. Pyne, Henry (ed) (1850). A Treatise Proving by The Common Law that The Pope Never Had Right to Any Supremacy in England. London: Shaw and Sons.

6. Sotheby (1886). Catalogue of the Library of the Late Henry Pyne, Esq. London: Dryden Press.

Secondary sources

7. Bell, Duncan (2007). The Idea of Greater Britain: Empire and the Future of World Order, 1860-1900. Princeton NJ: Princeton University Press.

8. Briggs, Asa (2008). A History of Longmans and their Books, 1724-1990: Longevity in Publishing. London: British Library.

9. Calzada Pérez, María (2003) 'Introduction' in María Calzada Pérez (ed.) Apropos Ideology: Translation Studies on Ideology - Ideologies in Translation Studies. Manchester: St. Jerome. 1-22.

10. Genette, Gérard (1997). Paratexts: Thresholds of Interpretation, trans. by Jane E. Lewin. Cambridge: Cambridge University Press.

11. Gill-Bardají, Anna, Pilar Orero and Sara Rovira-Esteva (eds) (2012). Translation Peripheries: Paratextual Elements in Translation. Bern: Peter Lang.

12. Harvey, Keith (2003). “Events' and 'Horizons': Reading Ideology in the 'Bindings' of Translations' in María Calzada Pérez (ed.) Apropos Ideology: Translation Studies on Ideology Ideologies in Translation Studies. Manchester: St. Jerome. 43-70

13. Koditschek, Theodore (2011). Liberalism, Imperialism and the Historical Imagination: Nineteenth-Century Visions of a Greater Britain. Cambridge: Cambridge University Press.

14. Kovala, Urop (1996). Translations, Paratextual Mediation and Ideological Closure. Target 8(1), 119-147.

15. Pellatt, Valerie (ed) (2013). Text, Extratext and Paratext in Translation. Newcastle upon Tyne: Cambridge Scholars Publishing.

16. Tahir-Gürçaglar, Şehnaz (2002). 'What Texts Don’t Tell: The Use of Paratexts in Translation Research' in Theo Hermans (ed.) Crosscultural Transgressions: Research Models in Translation Studies II, Historical and Ideological Issues. Manchester: St. Jerome. 44-60. 


\title{
Перевод на службе Более Великой Британии
}

\author{
Саймон МакКиннон \\ Дарэмский университет \\ Школа современных языков и культур \\ Элвет Риверсайд, Нью Элвет, Дарэм DH1 3JT
}

Франиузский текст позднего Средневековья Débat des Hérauts d'armes не обнаруживает явного аргумента в поддержку ранних или более поздних британских имперских устремлений. Он даже не представляет англичан в достаточно хорочем свете. Понимание перевода данного текста, выполненного Генри Пайном в 1870 году, в качестве средства для продвижения того, что его современник сэр Чарльз Дилк определил как Более Великая Британия, будет, таким образом, проблематичным. Тем не менее в этой статье отстаивается точка зрения, что, окружив свой перевод обширным паратекстуальным материалом, Пайн представляет свой текст в качестве важного документа, позволяющего объяснить исторические отнотения Великобритании с Европой и остальным миром. В частности, понимание Жаннетом паратекстов как средства для ограничения интерпретирующих вариантов читателей будет использоваться для изучения способов, с помощью которых Пайн (через название, предисловия, постраничные сноски и примечания, определение авторства и заключение) обеспечивает чтение текста соответственно интерпретации истории для поддерживания определенного набора британских идей конща ХІХ века о гонке, национальном характере и англосаксонской колониальной «судьбе». Именно поэтому данная работа предлагает дальнейтее понимание способов, посредством которых перевод был использован не только для оспаривания главного культурного дискурса, а скорее для развития и укрепления доминирующих идеологических позищий.

Ключевые слова: история перевода, паратексты, Более Великая Британия, Débat des Hérauts d'armes.

Научная специиальность: 10.00.00 - филологические науки. 